\section{The Use Of Short Stories In Communicative And Student-Centered Approach To Language Instruction From An Uzbek Perspective}

\section{Kukiboeva Mahliyo Mahmudjanovna,}

\author{
Independent Researcher, Namangan State University, \\ Uzbekistan \\ Visiting Scholar In Applied English Center, University Of \\ Kansas, Us
}

\author{
G OPEN ACCESS \\ The American Journal \\ of Applied Sciences \\ JULY 2020 \\ Page No.: 60-64 \\ Volume-II Issue-VII \\ PUBLISHED: 30 JULY 2020 \\ www.usajournalshub.com/inde \\ x.php/tajas \\ Copyright: Original content \\ from this work may be used \\ under the terms of the \\ Creative Commons Attribution \\ 4.0 licence.
}

Abstract: Current article outlines the benefits and peculiarities of using short stories and story based activities in communicative approach to language instruction and there are some suggestions for language teachers to make their classes more interactive.

Key words: Short story, communicative language teaching, activities, fluency, accuracy, meaningful tasks, linguistic competence, authenticity, genuineness.

\title{
Introduction
}

Present days while the need for English language learning and teaching is increasing rapidly, it is one of the primary tasks of all foreign language teachers, not only to master the rich experience and best practices of methodologists, scholars of this field, but also to share their own experience, findings and successful practices in their instructional context with their colleagues. Rod Bolitho, an internationally renowned English scholar, who is the author of famous methodological books in EFL claims that no teacher can be the same as he was at the time when he just started his career after lots of years of teaching. Because every lesson, every hour that is spent on teaching is a great source of experience for every teacher.

In the experience of Uzbekistan, there are fundamental enhancement and reformations are being implemented into all spheres of life including educational system. 
The president's decree number 1875 on the measures of the development of foreign language teaching which was signed on December 10, 2012 and deeply concerns both language teachers and young specialists who need professional growth in harmony with modern demands of improving the quality of education in the country. For that the initiatives should be started with teachers themselves.

As the demand for learning languages is rising today, the demand for development of new effective methods and approaches in language teaching, creating appropriate materials for modern classroom teaching and for new specialists is also increasing. One of the methods that has been among those employed most successfully and implemented widely in leading foreign language instruction in the USA, Europe and in many other countries of the world is Communicative approach to language instruction.

As a language instructor and teacher trainer I have witnessed hundreds of secondary school language teachers and instructors classroom teaching who call their teaching student-centered and communicative, where they try to make the process much more active with student participation and interactive, still there is huge need for teachers to realize the concept of student-centeredness and authentic communication-oriented teaching, and the use of authenticity in language teaching.

Famous English Scholar Jack C. Richards who is internationally renowned specialist in second and foreign language teaching, an applied linguist and an educator, the author of numerous professional books for English language teachers, claims in his book named " Communicative language teaching today " the classes that employ communicative approach to language teaching and student centeredness in language instruction are specified by the following characteristics:

- In teaching process developing communicative competence takes privilege over linguistic competence

- Mostly authentic (and semi-authentic) materials are used in foreign language instruction i.e classroom activities, tasks and assignments are developed for students on the base of genuine resources

- New lexical and grammatical materials are presented in context

- Grammar instruction is presented not only with isolated sentences and rules but also in context they are retrieved in students' mind by meaningful and engaging tasks. Initially, the views and ideas of students about the task are asked while counting on them in presenting a new theme

- Grammar should be taught implicitly rather than explicitly

- The knowledge of language is in harmony with intercultural, socio linguistic and pragmatic awareness raising activities in classroom environment

- It emphasizes the freedom of students over the dominancy of a teacher in the classroom and stresses to shape the ability of learner autonomy of students. 
- Real reasons for communication are promoted, grammar rules and structures are taught by exposing them to real communication, not by making the students learn by heart a grammar rule itself.

- It stresses to improve both the knowledge of language and fluency in speech at the same time.

- Teachers lessen their "talk time" by engaging learners in discovering new elements of real communication and language awareness themselves

- Language is learned more effectively by discovering, experimenting, by doing as it is a skill

Having taken into consideration above mentioned statements, initially, short stories can be valuable authentic resource to be implemented into communicative approach to language instruction. Authenticity as an ELT notion started to be highlighted and used widely with the advent of communicative language teaching in the 1970s. Invention of internet and the opportunities that it made available to access to diverse language materials, played important role for the term of authenticity to be defined and emphasized in language education context. In ELT professional discourse, there exist different definitions for the concept of authenticity that were outlined by different scholars of the field such as Gilmore (2007), Widows, Richards and others.

Having experimented many different stories with the diverse of methods and techniques in the varieties of classrooms and contexts it is worth suggesting their benefits and advantages as followings:

The availability and richness of stories in every language, especially in language instruction it gives great opportunity for teachers to choose short stories suitable for students' level and develop activities and tasks to improve speaking comprehension and production, reading and listening comprehension skills of students and especially, short stories are considered ready context that creates authentic environment for students to improve their vocabulary range in context in a foreign language, be aware of new grammar rules and to practice new grammar materials in context as well.

Apparently, short stories are rich in different expressions, idioms, collocations, proverbs and sayings. It develops the language and cultural awareness, of students enriching their knowledge of lexical layers. For example, origin of every proverb is specific for the nation and the place where they were originated and reflects the lexical and cultural specific features of them. In the lessons students will be aware of the literature, history, culture and lifestyle of the country whose language they are being learned. Famous Uzbek methodologist J.Jalolov claims in his book called "The methodology of foreign language teaching" that the educating procedures of young generation can be characterized quality and worth when it is carried in harmony with developing their morality and personality. Thus, the function of language education is not only forming awareness of how a certain language is structured, but also interweave and enrich the 
ELT process with the function of developing personalities, moralities and cultural understanding.

In bringing up young generation the role of short stories is irreplaceable and extremely valuable in every culture. It has been trialed and approved throughout the centuries that stories are very strong tool for teachers and educators to form students understanding about life, to teach them exemplary behavior and to master young generations' humanistic qualities and culture and foster strong personalities that can be useful for national and international development and civilization of the world. In particular, the colorful and diverse topics of short stories make it possible to apply them in different language classes with different focuses and of all themes. For instance, heroism, humanism, homeland, the value of knowledge and learning, lifestyles, health, tolerance, family matters, honesty, kindness, loyalty, norms of behavior, importance of hard work , profession, and many other topics covered in syllabus and curriculum of academic educational institutions. Besides, short stories are the source of diversity of tasks, exercises and assignments which make it possible to design different activities for all grammar and lexical themes and topics including, set expressions, idioms, antonyms, synonyms, homonyms, parts of speech, types of sentences, verb tenses, moods, voice, reported speech and many others.

As a conclusion we can summarize these advantages of implementation of short stories in communicative language teaching:

- Short stories are considered as the resource of authentic materials and tasks

- They give an opportunity to learn lexical and grammar materials in context

- They give great chance of teaching language education and developing morality and personality in harmony

- They develop learners' language skills, such as listening and reading comprehension, writing and speaking in integration

- They help to form and enhance communicative competence and intercultural awareness of learners.

- They interlink language education with other subjects and fields of study

- They are suitable for language learners' with different language levels and they are diverse source of lexical and grammatical themes

- Storytelling is one of the best ways of teaching pronunciation

- Using stories in the forms of different tasks can serve as developing motivation and inspiration of learners

- Short stories are rich source for material designing and developing engaging, meaningful and communication promoting tasks and activities for interactive classes. 
- By great varieties of classroom activities and tasks based on stories we can lessen teachers' 'talk time' and create more opportunity for learners to talk, to experiment language use and discover new knowledge for them.

\section{Conclusion}

In conclusion, we can say, when we language teachers can apply short stories in language instruction appropriately, we can make our classroom teaching not only engaging and meaningful but also very effective and communicative.

\section{REFERENCES}

1. Jack C.Richards. Communicative Language Teaching Today. Cambridge University Press, 2006

2. Sowden,C.Culture and the good teacher in the English language Classroom.ELT journal, 2007 vol.61/4pp.304-310

3. J. Jalolov, Methodology of foreign language teaching, Tashkent, " Uqituvchi " Publications 1996

4. R Bolitho. Lectures for Uzbek teachers at NILE, 2013

5. www.britishcouncil.org/learnenglish

5. www.teachingenglish.org.uk 